\title{
METHODICS OF ASSESSING ENVIRONMENTAL NOISE EMISSION WHILE PERFORMING HYDRAULIC FRACTURING OPERATIONS IN SHALE FORMATIONS**
}

\section{INTRODUCTION}

Hydraulic fracturing operations performed at the stage of gas prospecting in shale formations are aimed at opening out gas residing in rock micropores. Large quantities of fracturing fluid, with physicochemical composition adjusted to their properties, are injected to the selected interval of a horizontal well. Finally, sand (proppant) is injected along with the fracturing fluid to support the newly formed fracture.

In the industrial practice, 10 to 15 stages are performed in a horizontal well section $1,000 \mathrm{~m}$ to $2,000 \mathrm{~m}$ long. The produced fracture generates propagation up to $300 \mathrm{~m}[2,5]$. Hydraulic fracturing operations involve specialist sets of devices powered by high-pressure motors totaling to a dozen to tens of thousands $\mathrm{kW}$. The duration of a hydraulic fracturing operations is $2 \mathrm{hrs}$ to $4 \mathrm{hrs}$, depending on the quantity of the injected fracturing fluid [3]. On average, a few such operations can be performed during a day period.

The most important environmental hazards which may accompany properly conducted fracturing of shale rock are mainly connected with noise emission from motors powering technological subassembies, aggregates and atmospheric pollution [1,3]. Most of these works are usually conducted in areas where the noise standards are not applicable. However, in some localizations the operations are conducted close to farmsteads and residences, where the respective environmental standards have to be met. According to Polish law, the acceptable noise levels measured on the level of windows in residential objects, equals to $L_{\text {Aeq }}=55 \mathrm{~dB}$ in the day time, and $L_{A e q}=45 \mathrm{~dB}$ in the night hours [10]. When the noise level is exceeded, sound berms have to be applied.

For the sake of evaluating the impact of the hydraulic fracturing of rocks on acoustic conditions in their area, noise propagation should be mathematically modeled. This calculation method is based on the Regulation of the Environment Minister of 30 October 2014

* AGH University of Science and Technology, Faculty of Drilling, Oil and Gas, Krakow, Poland

** The work performed within AGH-UST statutory research program no. 11.11.190.555. 
about measurements of emissions and quantity of intake water (Official Journal No. 2, item 1542) and standard PN-ISO 9613-2 Acoustics - Noise attenuation during outdoor propagation - General calculation method $[9,11]$. A lot of computer programs for environmental noise propagation are available on the market, nowadays. Here was used the LEQ Professional program, designed for predicting sound level around industrial utilities on the basis of theoretical and empirical data. It was based on a calculation model from the standard PNISO 9613-2 and Instruction ITB No. $338[4,9]$. This program enables one to determine the equivalent sound level at a selected point on the well pad, based on the known localization of noise sources, their acoustic parameters and characteristic of the area, taking into account the reduction of noise level by natural and designed barriers.

Standard PN ISO 9613 also includes engineering calculation methods for determining attenuation of environmental noise, to define its level at a certain distance from the source or many dominant noise sources. These methods can be used for predicting an equivalent continuous sound level A from a given receiver point, taking into account weather conditions as well as the attenuation and reflection from the surface. Calculation methods make use of algorithms for octave bands (nominal mid frequency $63 \mathrm{~Hz}$ to $8 \mathrm{kHz}$ ) and allow for calculating attenuation of sound from a point source [4, 9].

\section{THEORETICAL CALCULATION OF NOISE PROPAGATION AFTER STANDARD PN-ISO 9613-2}

The first equation used for sound level prediction defines equivalent, continuous sound level in octave band in a given receiver point, i.e. [9]:

$$
L_{f T}(\mathrm{Dw})=L_{W}+D_{C}-A
$$

where:

$L_{W}$ - sound power of the source in octave band, as compared to the power of $1 \mathrm{pW}$,

$D_{C}$ - directivity correction describing deviation in a given direction of equivalent sound level coming from a point source in relation to the sound level of the omnidirectional source $[\mathrm{dB}]$,

$A$ - attenuation in octave band $[\mathrm{dB}]$.

Attenuation in octave band is a sum of particular attenuations and is calculated with the following formula [9]:

$$
A=A_{d i v}+A_{a t m}+A_{g r}+A_{b a r}+A_{\text {misc }}
$$

where:

$A_{d i v}$ - attenuation due to geometric divergence,

$A_{\text {atm }}$ - attenuation due to atmospheric absorption,

$A_{g r}$ - attenuation due to 'ground' effect,

$A_{b a r}$ - attenuation due to screening by obstacles,

$A_{\text {misc }}$ - attenuation due to other effects. 


\section{Attenuation due to geometric divergence}

Attenuation due to geometric divergence depends on the distance between the noise source or sources, and a given receiver point [9].

$$
A_{\text {div }}=20 \log \frac{d}{d_{0}}+11
$$

where:

$d$ - distance between a source and a given receiver point [m],

$d_{0}-$ reference distance $=1 \mathrm{~m}$.

\section{Attenuation due to atmospheric absorption}

The attenuation due to atmospheric absorption is mainly influenced by the distance between the noise source or sources and a given receiver point and also coefficient of atmospheric absorption $\alpha$ [9].

$$
A_{\text {atm }}=\frac{a d}{1000}
$$

where:

$\alpha$ - coefficient of atmospheric absorption for each octave band $[\mathrm{dB} / \mathrm{km}]$,

$d$ - distance between the source and a given receiver point [m].

\section{Attenuation due to sound reflection from the ground surface}

The value of $A_{g r}$ is determined by the sound reflection from the ground surface, i.e. 'ground' effect. Attenuation is mainly caused by the ground surface localized close to the source and close to the given receiver point. The attenuation can be calculated on the basis of an assumption that the ground surface is smooth, rather horizontal or with constant inclination. Three areas for the 'ground' effect can be distinguished [9]:

- source area - a distance from the noise sources towards the given receiver point of a length $d_{p}=30 \mathrm{~h}_{\mathrm{s}}$ (maximum length $d_{p}$ ), where $\mathrm{h}_{\mathrm{s}}$ is the height of the source. In the case of hydraulic fracturing operations, the assumed height of source is $2.0 \mathrm{~m}$. Then parameter $d_{p}$ equals to $30 \times 2.0=60 \mathrm{~m}$.

- receiver area - a distance from a given receiver point towards the source of length $30 h_{r}$ (maximum length $d_{p}$ ), where $\mathrm{h}_{\mathrm{r}}$ is the height of a given receiver point. When calculating noise propagation with on-going hydraulic fracturing, the height of a given receiver point is assumed to be of $1.5 \mathrm{~m}$.

- middle area - a distance between the source and the receiver. If $d_{p}$, equals to $30 h_{s}+30 h_{r}$, the source area and the receiver area partly coincide.

The acoustic properties of each area can be established with coefficient $G$ for three categories of ground surface [9]:

- hard surface, e.g. asphalt, water, ice etc. $G=0$,

- porous surface, e.g. covered with grass, trees etc. $G=1$,

- mixed-type surface has elements of hard and porous surfaces $0<G<1$. 
Attenuation due to the 'ground' effect is determined with the use of equation (5).

$$
A_{d r}=A_{s}+A_{r}+A_{m}
$$

where:

$A_{s}-$ attenuation in source area,

$A_{r}-$ attenuation in a given receiver point area,

$A_{m}$ - attenuation in the middle area.

Methods of calculating parameters $A_{s} ; A_{r}$ and $A_{m}$ are presented in standard PN-ISO 9613-2 [9].

In most cases the prospecting or production works are conducted in agricultural or forest areas, therefore $G=1$ is frequently assumed in the calculations.

\section{Attenuation due to screening by obstacles}

For calculating the noise attenuation due to screening by obstacles, attention should be paid to the sound wave diffraction on the upper edge or side edges of the obstacle. In the area, where hydraulic fracturing is conducted, we mainly have to do with two types of obstacles: earth berm and containers on the well pad. Here we have a double diffraction effect (Fig. 1).

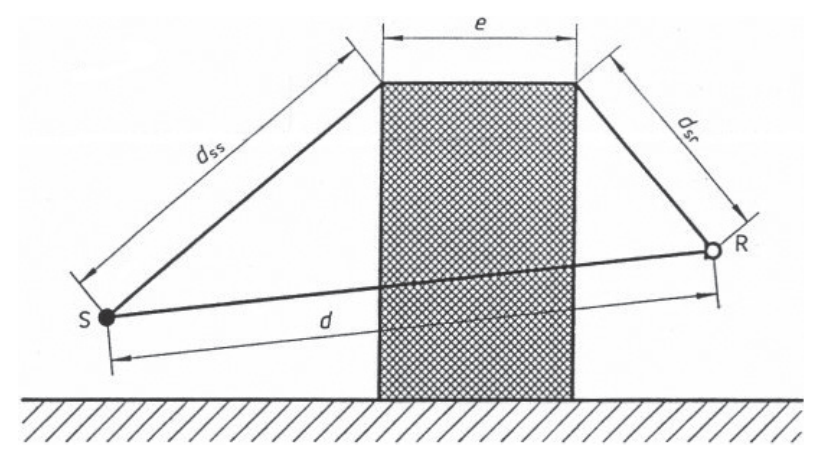

Fig. 1. Model for calculating coefficient $C_{3}$ for a double diffraction of a wave [9]

Wave diffraction on the upper edge is defined from the formula:

$$
A_{b a r}=D_{z}-A_{g r}>0
$$

Diffraction on the side edges is calculated from:

$$
A_{\text {bar }}=D_{z}
$$

where:

$D_{z}$ - attenuation due to the screening of obstacles in each octave band,

$A_{g r}$ - attenuation due to the 'ground' effect, if the obstacle is absent.

Attenuation due to the screening of obstacles in each octave band is defined from the equation (8). 
where:

$$
D_{z}=10 \log \left[3+\frac{c_{2}}{\lambda} \cdot C_{3} \cdot z \cdot K_{m e t}\right]
$$

$C_{2}=20 \mathrm{~dB}$ (includes reflection from the surface and in some cases may be equal to $40 \mathrm{~dB}$ ),

$C_{3}$ - for double diffraction is determined from equation (9).

where:

$$
C_{3}=\frac{1+\left(\frac{5 \lambda}{e}\right)^{2}}{\frac{1}{3}+\left(\frac{5 \lambda}{e}\right)^{2}}
$$

$\lambda$ - wavelength (for the frequency of middle octave band),

$K_{\text {met }}$ - coefficient of atmospheric correction,

$z$ - difference between the length of trajectory of wave diffracted on the obstacle and without the obstacle,

$E$ - distance between two diffraction edges.

For a double diffraction the difference between the trajectory of a wave diffracted on an obstacle and without such an obstacle is determined from equation (10).

$$
z=\left[\left(d_{s s}+d_{s r}+e\right)^{2}+a^{2}\right]^{\frac{1}{2}}-d
$$

The coefficient of atmospheric correction $K_{m e t}$, is defined from formula (11).

$$
K_{m e t}=\exp \left[-(1 / 2000) \sqrt{d_{s s} \cdot d_{s r} \cdot \frac{d}{2 z}}\right]
$$

\section{Reflection from the surface}

The effect of reflection from the surface takes place when the acoustic wave reflects from the sound barriers. Reflection from most of the obstacles can bring about a negative effect increasing the noise level in a given receiver point.

The apparent source power level is determined from equation:

where:

$$
L_{w, i m}=L_{w}+10 \log \rho+D_{i r}
$$

$\rho-$ reflection coefficient (Tab. 3),

$D_{i r}$ - directivity index of source.

Exemplary values of reflection coefficient for various surfaces are listed in Table 1.

Table 1

Exemplary values of acoustic coefficient of wave reflection $\rho$ [9]

\begin{tabular}{|l|c|}
\hline \multicolumn{1}{|c|}{ Object } & Reflection coefficient $\rho$ \\
\hline Walls & 1 \\
\hline Walls with windows & 0.8 \\
\hline Walls with openings constituting 50\% of surface & 0.4 \\
\hline
\end{tabular}


There are lots of barriers in the rig area which may give the reflection effect, e.g. office and technical containers or earth berms around the rig. If they are localized in a wrong place, they may deteriorate the acoustic conditions at points which need to be protected. Therefore, performing mathematical simulations of noise propagation prior to the hydraulic fracturing operations is very important. Correctly distributed sound berms and containers in the rig area may significantly minimize the environmental noise emission.

\section{Other types of attenuation $\left(A_{\text {misc }}\right)$}

During noise propagation from the rig area to the environment, additional attenuation effects may take place, e.g. [9]:

$-A_{\text {fol }}$ - noise attenuation in green areas,

- $A_{\text {site }}-$ noise attenuation in industrial areas,

- $A_{\text {hous }}-$ noise attenuation in residential areas.

The environmental noise emission from the rig area can be limited in green areas. This is especially important when the surrounding of the area undergoing hydraulic fracturing is covered with trees and bushes $[4,9]$. Noise is attenuated mainly by vegetation growing close to the given receiver point (Fig. 2).

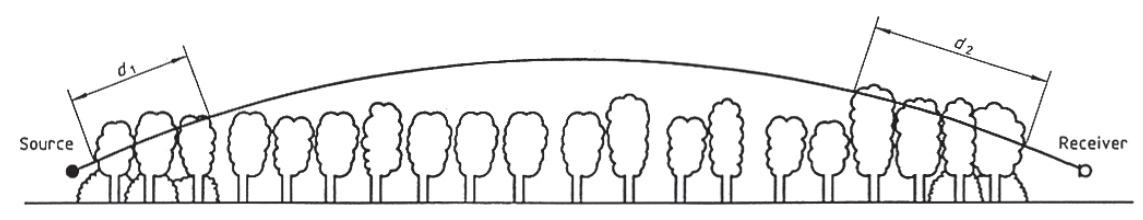

Fig. 2. Noise attenuation in area grown with vegetation [9]

\section{ENVIRONMENTAL NOISE PROPAGATION ACCOMPANYING HYDRAULIC FRACTURING OPERATIONS}

For the sake of determining the range of environmental noise propagation during hydraulic fracturing operations in shale rock, a mathematical simulation was performed for a real well pad localized on a concession in the north of Poland. Environmental noise was measured while conducting hydraulic fracturing operations. In this way the results of noise emission obtained through the computer simulations were compared with the actual noise level around the well pad.

The hydraulic fracturing operations involved using 18 high pressure pumps of acoustic power $110 \mathrm{~dB}$ and two blenders of acoustic power $105 \mathrm{~dB}$. The duration of hydraulic fracturing was $2.5 \mathrm{hrs}$.

The well pad was partly protected with an earth berm $3.5 \mathrm{~m}$ high, artificially formed from the removed humus layer. Additionally, the containers of up to $3 \mathrm{~m}$ high played the role of barriers. The way in which the well pad was managed and the noise berm are presented in Figure 3.

At a distance of $320 \mathrm{~m}$ from the rig area to the southwest there was the closest protected area, i.e. farmstead, and residential houses at a distance of about $550 \mathrm{~m}$. A deciduous forest was growing on the east and south side at a distance of $50 \mathrm{~m}$ (Fig. 4). 

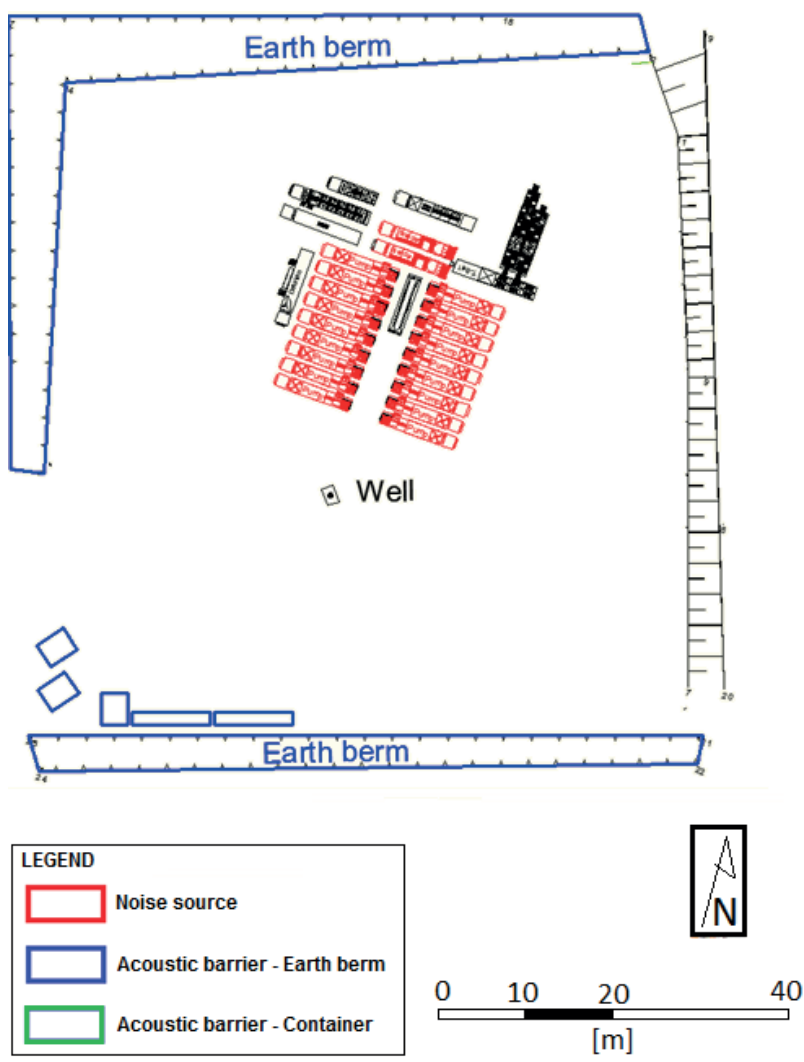

Fig. 3. Localization of noise sources and acoustic barriers on the well pad

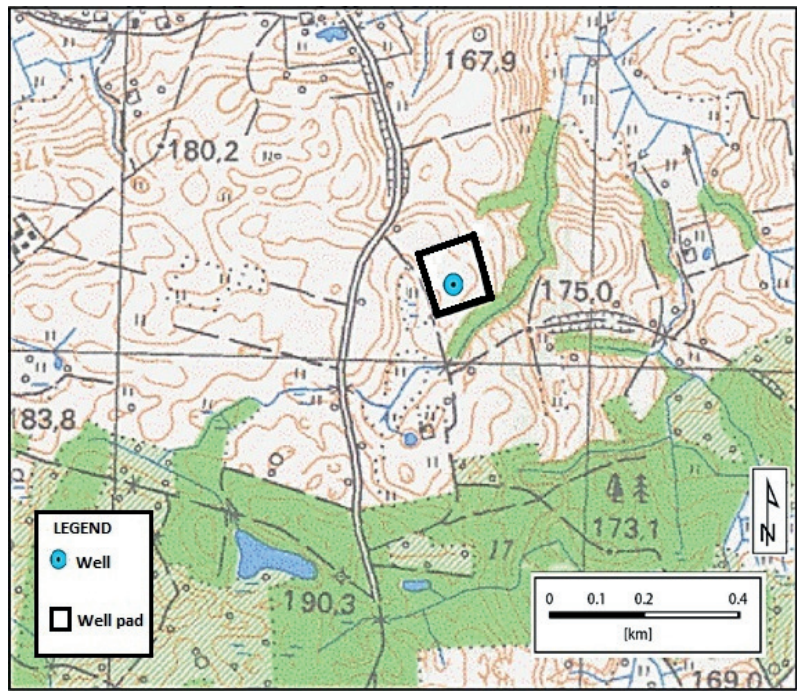

Fig. 4. Localization of the well pad 


\section{Modeling of noise propagation during hydraulic fracturing operations}

The simulation of sound propagation in the area of on-going hydraulic fracturing operations, was based on the following assumptions:

- among the sound barriers in the well pad are all buildings which do not emit noise, and earth berms;

- the acoustic power level of machines emitting noise was assumed on the basis of catalog data; it equaled to $110 \mathrm{~dB}$ for high-pressure hydraulic pumps, and $105 \mathrm{~dB}$ for blenders;

- calculation grid $50 \mathrm{~m} \times 50 \mathrm{~m}$;

- flat work area, landscape not accounted for;

- height of noise source $2 \mathrm{~m}$;

- calculations performed for points at $1.5 \mathrm{~m}$ a.s.;

- reflection coefficient $\rho=1$;

- coefficient of attenuation of noise due to surface reflection $G=1$;

- height of vegetation area (trees) $15 \mathrm{~m}$;

- air temperature $10^{\circ} \mathrm{C}$;

- relative humidity $70 \%$.

The sound level was determined in 7,225 reception points within the scope of the computer simulation. The sound level intensity was calculated for each reference point using previously described relations, i.e. the location of the reference point against noise sources, atmospheric absorption, attenuation due to ground surface reflection, surface reflection effect and attenuation due to sound propagation in vegetation grown areas. The distribution of sound level in the form of isophones $45 \mathrm{~dB}$ and $55 \mathrm{~dB}$ was presented on the map (Fig. 5). Isophones correspond with admissible noise level in the night hours $(45 \mathrm{~dB})$ and during the day $(55 \mathrm{~dB})$.

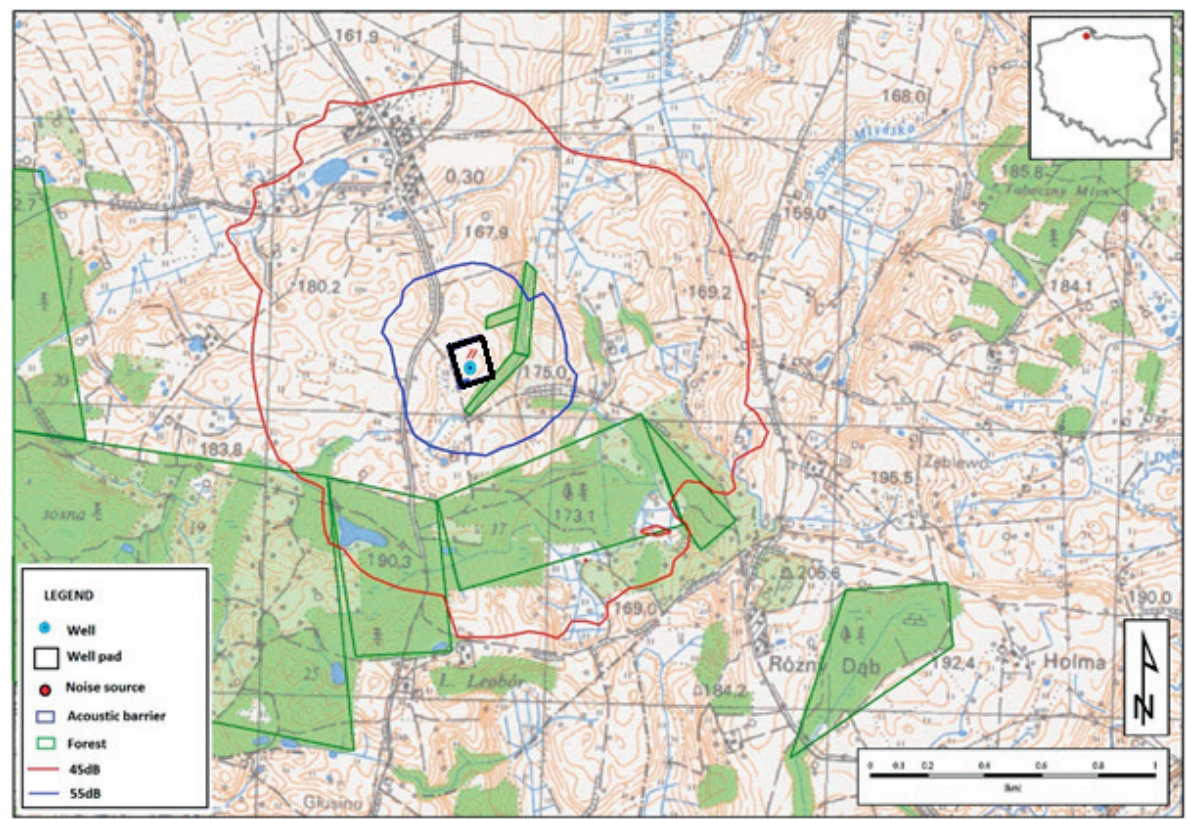

Fig. 5. Map of noise around the well pad during hydraulic fracturing operations - simulation 


\section{Noise measurement during hydraulic fracturing operations}

Noise measurements in the close vicinity of the well pad were performed in line with the Regulation of the Environment Minister of 30 October 2014 concerning requirements with regard to measuring emission volumes and measuring the quantity of collected water (Official Journal 2014, item 1542) and standards PN-ISO 1996 [6-8, 11]. The environmental noise was measured with the use of a sound analyzer Sonopan SON-50 of accuracy class 1, with valid validation certificate. The measuring microphone was equipped with a windshield. Prior to the environmental noise measurement, the device was calibrated with a calibrator of accuracy class 1 . During the environmental noise measurements with a time weightings $F$ (Fast) and a frequency characteristic $A$, the microphone was placed $1.5 \mathrm{~m}$ above the ground surface.

The hydraulic fracturing operations were realized during the day time and only for these hours the environmental noise emission was measured. For the sake of assessing the range of the standard noise level in the night hours (isophone $45 \mathrm{~dB}$ ), the results of the measurements performed during day hours were assumed in the calculations. This assumption is correct as the sound emitted by technological utilities engaged in hydraulic fracturing can be treated as continuous.

The noise measurements performed during hydraulic fracturing operation were made in 33 points with the sampling method. The time of noise measurement at each point equaled to $60 \mathrm{~s}$. The noise measurement was performed during the day and compared to the acoustic background (33.4 dB). A map of noise distribution around the rig was worked out with the use of a Surfer program (Fig. 6).

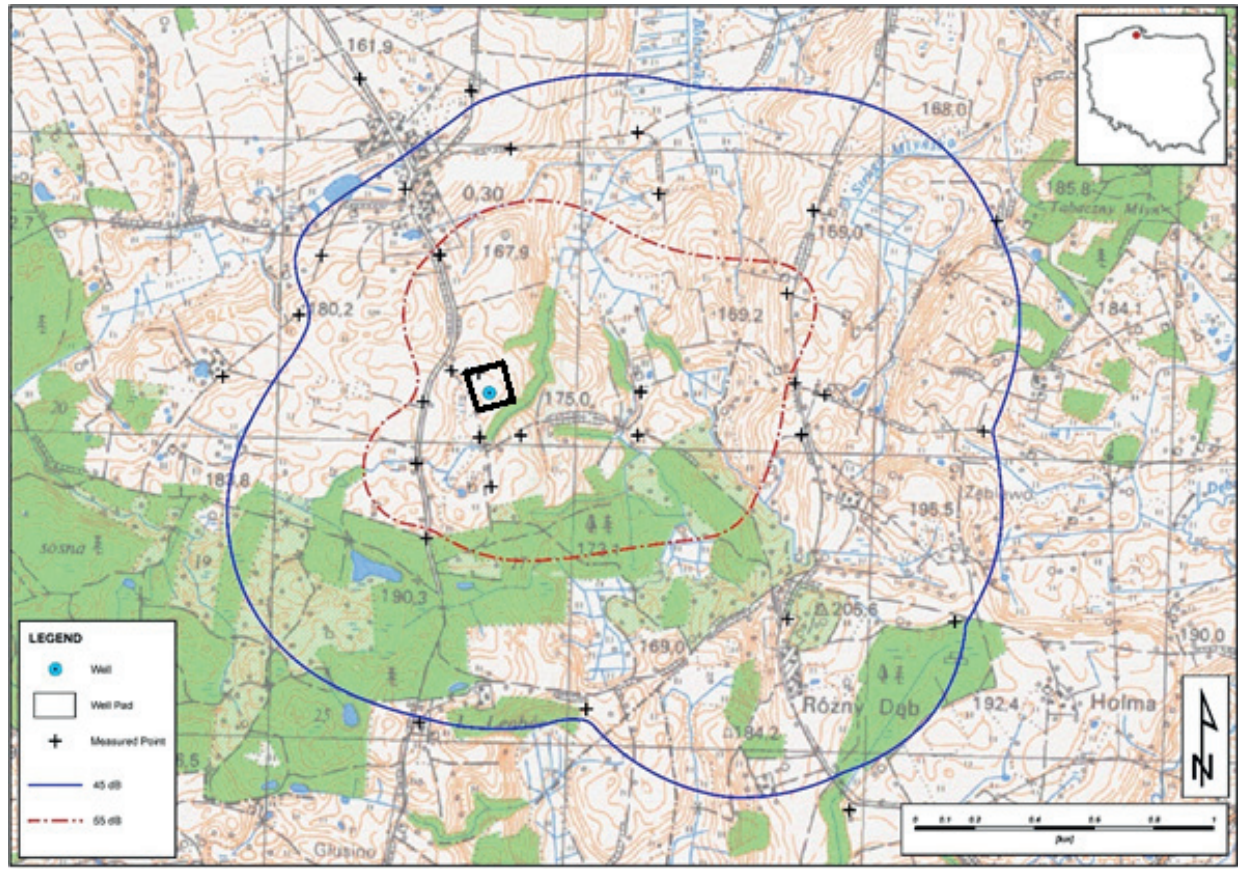

Fig. 6. Map of noise around the well pad during hydraulic fracturing operations - noise measurements 


\section{ANALYSIS OF RESULTS \\ OF NOISE PROPAGATION SIMULATIONS}

The analysis of the results of a computer simulation of noise propagation around the well pad and the results of the analyses of sound level around the well pad vicinity in the course of hydraulic fracturing operations reveals that the range of the normative sound level values in the day time and during the night and calculated with the use of a LEQ Professional program considerably differ from the real ones, measured in the field conditions. The range of isophones $55 \mathrm{~dB}$ for day hours and $45 \mathrm{~dB}$ for night hours, calculated on the basis of a computer simulation, was much lower than the ranges measured in field conditions. The range of isophone $45 \mathrm{~dB}$ established on the basis of the computer simulation for the least favorable point in terrain equaled to $400 \mathrm{~m}$, whereas in the field condition such a value was measured for a distance of $1,300 \mathrm{~m}$. A similar character of noise distribution was observed for isophone $55 \mathrm{~dB}$. The value $55 \mathrm{~dB}$ calculated through computer simulation was noted at a distance of $1,100 \mathrm{~m}$ from the well pad, whereas in the field measurements showed to the range of $1,800 \mathrm{~m}$.

The results of a computer simulation of noise distribution around the well pad were mostly affected by the lack of reference to the topography data in the calculations. It was assumed in the computer simulations that the entire work area was localized on a flat level, whereas in reality the terrain was very uneven, dropping to the east and southeast (Fig. 2). On the western side of the well pad there was an elevation ( $5 \mathrm{~m}$ difference in height), which additionally had an effect on the noise propagation in the terrain.

The analysis of the computer simulation results and measurements reveal that the earth berm failed to play the role of a sound barrier. The height of the berm, i.e. $3.5 \mathrm{~m}$ turned out to be insufficient to limit the noise emission towards the buildings requiring acoustic protection.

The computer simulation reveals that both residential houses and farmsteads were localized within the reach of isophone $45 \mathrm{~dB}$. None of the protected areas was within the reach of isophone $55 \mathrm{~dB}$. The noise measurements around the well pad show that the area with acoustic barriers had exceeded acceptable values for the day time $(55 \mathrm{~dB})$ and for the night $(45 \mathrm{~dB})$.

According to the Regulation of the Environment Minister of 14 June 2007 about the concerning acceptable noise levels in the environment (Official Journal No. 120, item 826), the acceptable noise levels in the day time $L_{\text {AeqD }}(55 \mathrm{~dB})$ refers to the eight least favorable successive hours, and only to one least favorable hour in the night hours $L_{\text {AeqN }}(45 \mathrm{~dB})[10]$. This means that the normative noise level in the day time would be exceeded only if the hydraulic fracturing operations lasted uninterruptedly over $8 \mathrm{hrs}$. It should be observed that a technological break is organized between hydraulic fracturing operations to install a plug in the well and perforate the casing, which may take a few hours. Hence, a conclusion that in the case of hydraulic fracturing operations performed in the day hours, even after a few stages, the acceptable environmental noise level will not be exceeded.

In the case of hydraulic fracturing operations performed at night, the acceptable sound level of $45 \mathrm{~dB}$ would be exceeded in the first hour of work. The hydraulic fracturing operations can be conducted at night only if the distance between the well pad and the protected area is minimum $1800 \mathrm{~m}$ or sound barriers are installed to reduce the noise level to the required values. 


\section{CONCLUSIONS}

The analysis of noise emission measurements during performing hydraulic fracturing operations in shale rock for natural gas prompts the following conclusions:

1) The average measured range of isophone $45 \mathrm{~dB}$ (most frequent acceptable value for night hours in exploration areas) and isophone $55 \mathrm{~dB}$ (for day time) equals to $1,800 \mathrm{~m}$ and $1,300 \mathrm{~m}$, respectively.

2) The range of impact obtained for isophones $45 \mathrm{~dB}$ and $55 \mathrm{~dB}$ in computer simulations considerably differed from the results of sound level measurements in the field and equaled to $900 \mathrm{~m}$ for the day time and $700 \mathrm{~m}$ for the night hours. The main cause of the calculation error was the lack of possibility of introducing landscape data to the program.

3) The hydraulic fracturing operations, even the gradual ones, can be conducted during the day period if hydraulic fracturing operations of one section does not last longer than $8 \mathrm{hrs}$.

4) If hydraulic fracturing operations are performed during night hours, a sound barrier should be elevated. This is necessary when objects needing a sound protection are localized up to $1800 \mathrm{~m}$ from the source.

5) Earth berms made of soil around the well pad to a height of $3.5 \mathrm{~m}$ do not meet the requirements of acoustic barriers.

\section{REFERENCES}

[1] EIA: Assessment of risk from Unconventional Gas Well Development in the Marcellus Shale of Western Maryland. January 20, 2015.

[2] EIA: Technically Recoverable Shale Oil and Shale Gas Resources: An Assessment of 137 Shale Formations in 41 Countries Outside the United States, Washington D.C. 2013. http://www.eia.gov/analysis/studies/worldshalegas/pdf/overview.pdf.

[3] Environmental Impacts of Fracking Related to Exploration and Exploitation of Unconventional Natural Gas Deposits. Risk Assessment, Recommendations for Action and Evaluation of Relevant Existing Legal Provisions and Administrative Structures. Dessau-Roßlau, September 2013.

[4] https://www.umweltbundesamt.de/sites/default/files/medien/378/publikationen/texte.

[5] Instrukcja ITB nr 338/2003. Metoda określania emisji i imisji hałasu przemysłowego w'środowisku ITB. Warszawa 2003.

[6] Macuda J.: Środowiskowe aspekty produkcji gazu ziemnego z niekonwencjonalnych złóż. Przegląd Geologiczny, t. 58, nr 3, 2010.

[7] Polska Norma PN-ISO 1996-1: Akustyka. Opis i pomiary hałasu środowiskowego. Podstawowe wielkości i procedury, marzec 1999.

[8] Polska Norma PN-ISO 1996-2: Akustyka. Opis i pomiary hałasu środowiskowego. Podstawowe wielkości i procedury, marzec 1999.

[9] Polska Norma PN-ISO 1996-3: Akustyka. Opis i pomiary hałasu środowiskowego. Podstawowe wielkości i procedury, marzec 1999. 
[10] Polska Norma PN-ISO 1913-2: Akustyka. Ttumienie dźwięku podczas propagacji w przestrzeni otwartej. Ogólna metoda obliczeniowa, wrzesień 2002.

[11] Rozporzadzenie Ministra Środowiska z dnia 14 czerwca 2007 r. w sprawie dopuszczalnych poziomów hałasu w środowisku. Dz.U. 2007, nr 120, poz. 826.

[12] Rozporządzenie Ministra Środowiska z dnia 30 października 2014 r. w sprawie wymagań w zakresie prowadzenia pomiarów wielkości emisji oraz pomiarów ilości pobieranej wody. Dz.U. 2014, nr 2, poz. 1542. 